\title{
クロマグロと沿岸魚種との相互関係について
}

\author{
土 井 長 之 \\ (1959 年 10 月 12 日受理)
}

\section{ON THE PREDATORY RELATIONSHIPS AMONG BLUEFIN TUNA AND COASTAL FISHES IN THE SOUTHERN WATERS OF JAPAN}

\author{
Takeyuki Dor*
}

As to theoretical models of prey-predator relationships among fishes, VOLTERRA's differential equations are well-known. Nevertheless, there are a great deal of criticism that those equations cannot stand for real circumstances of community of fishes or animals. But as the equations are convenient to examine the community problems of fishes, discussions about the equations are now often presented.

This report is a trial to prove whether VolTERRA's equations are applicable to the predatory relationships between bluefin tuna, a predator, and coastal fishes in the southern waters of Japan. An electronic analogue computer was employed in solving the equation which is a kind of non-linear differential equations.

The following are the results obtained. First, relationships between bluefin tuna and common squid in the waters for the years 1951 to 1955 have been examined. In Fig. 2 the broken line, generated by a function fitter of the analogue computer, represents the actual variations in the stock of common squid for the years 1951 to 1955, and the other curves stand for the theoretical variations in the bluefin tuna computed by the analogue computer for various values of a parameter of VolTERRA's equation. The graphical form in the middle of theoretical curves is similar to an actual variation of bluefin tuna. Therefore, as far as those years are concerned, it seems that these two fishes are in prey-predator relationships fitted to VoLTERRA's equation.

In the second place, for the years 1951 to 1956 instead of to 1955, it was found impossible to make a theoretical graphical form similar to actual variations of bluefin tuna. But when total catch of coastal fishes is considered instead of common squid alone, it is possible to find out the predatory relationships between bluefin tuna and the sum of coastal fishes for the year 1951 to 1956, as shown in Fig. 4.

From these results it is concluded that bluefin tuna and coastal fishes including common squid are in predatory relationships in the southern waters of Japan.

\section{1. まえがき}

生物社会に和ける競存関係の理論的な取报としては VOLTERRA の方程式がよく知られている。この式が

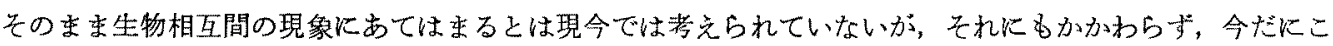

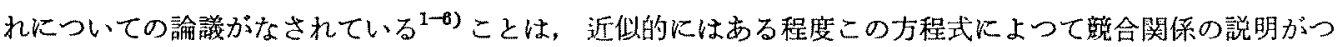
くためである。この報告はクロマグロと沿岸魚種との関係が VOLTERRA の方程式によつてどの程度に説明 されるかを定性的に調ぺたものである。VOLTERRA の式は数学的にはいわゆる非線型の式であるから-一般 的にはなかなか解き難いがの，フナログコンピューターを使えばこの点は克服される。

\section{2. アナロタコンピューターによる VOLTERRA の式の解法}

捕食魚の筫源量を $y$ ，その慨料生物の量を $x$ とすれば $x, y$ の時間的変化を規制する VOLTERRA の式は

* 東海区水産研范所 (Tokai Reg. Fish. Res. Lab.).

東海区水産研究所業縝 B 第 325 号 
つぎのようになる。

$$
\begin{aligned}
& \frac{d x}{d t}=A x-B y \cdot x \\
& \frac{d y}{d t}=-C y+D x \cdot y
\end{aligned}
$$

ここで $B$ 特よび $D$ がそれぞれ生物相互間の関係をあらわす係数である。この報告では $y$ とててクロマグ

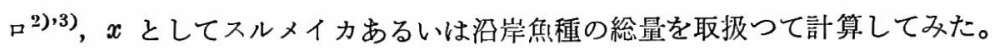

(1) 式と (2) 式の連立微分方程式を解いて実際の漁獲変動を比較することをアナログコンピューターで行 5場合, 二通りの計算方式が考学られる。1つはある年 $(t=0)$ の実際の資源量を $\left(x_{0}, y_{0}\right)$ とすれば, これ を初期条件として翌年 $(t=1)$ のもの $\left(x_{1}, y_{1}\right)$ は連立方程式を解いて求めることができる。つぎに $\left(x_{2}, y_{2}\right)$ をもとにして同様に $\left(x_{3}, y_{3}\right)$ を求め得る。これを順次くり返すことにより $x$ と $y$ の理論上の時間的変化が 求められる。この形と実際の漁獲変動の形とを比較することによつて実際の变化が VOLTERRA の式で解积 されるか否かがわかる。4つのパラメターについてはそれぞれいろいろな值を入れてみて計算しなければな らないのはもちろんで, いくつかの試行のうち形の合うものがあればその值を魚種間関係のパラメターであ ると推定する。

第 2 の方法は $y$ として実際の捕食魚の時間的変化をとり（これはフナログコンピューターでは任意函数 発生装置によつて可能である), (1) 式のみを解いて $x$ の理論的な時間的変化を求め, これが実際の $x$ と 合うか否かを比較する方法である。また逆に $x$ の実際の餪料魚種の時間的変化を任意発生函数発生装置で とつて (2) 式のみによつて $y$ を解いてもよい。この報告では第 2 の方法によつた。

\section{3. クロマクロとスルメイカの関係}

クロマグロと沿岸魚種との関係は南海区水域の問題として取上げられた歴史がある2゙,3) のでこの資料とよ つて計算をすすめた。Fig. 1 は南海区水域の昭和 26 年より 31 年末でのクロマグロとスルメイカの年変化 であつて, 太い実線が捕食魚としてのクロマグロ， 点線はクロマグロの䬣となるスルメイカである。沿

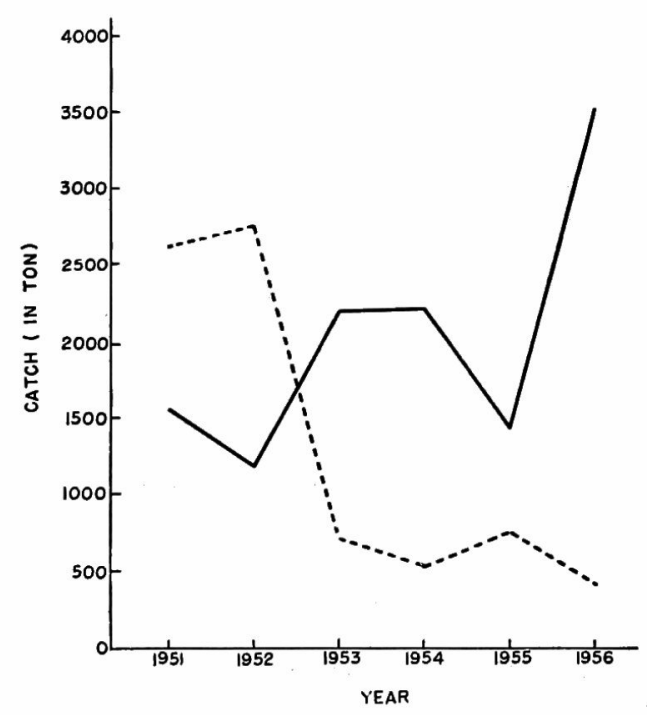

Fig. 1. Yearly variations in catch of bluefin tuna (solid line) as a predator and common squid (dotted line) as a prey in the southern waters of Japan for the years 1951 to 1956 .

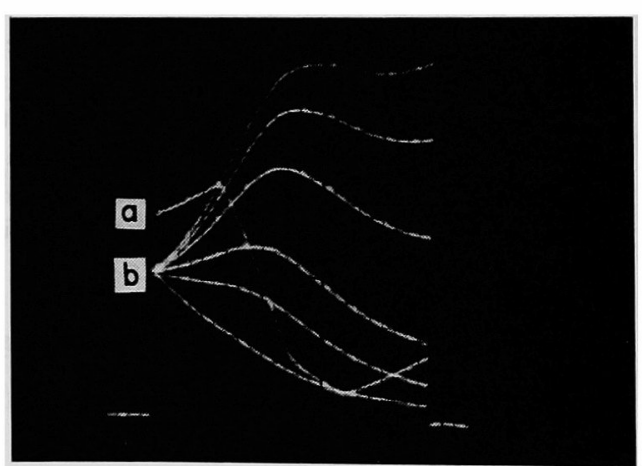

Fig. 2. Actual variation in common squid stock for the years 1951 to 1955 and theoretical variations of bluefin tuna computed by an analogue computer from Volterra's equation of predatory relationships. Broken line (a), generated by a function fitter of the analogue computer, represents the actual variation of common squid and assembly of curves (b) are the graphical forms of the theoretical variation of bluefin tuna for various values of a predatory parameter. One of the theoretical variations (the third line from above) approximates to actual one shown in Fig. 1. 
岸魚種のうちでは, スルメイカがクロマグロの慨として比重が大きいようである。

スルメイカを $(1),(2)$ 式の $x$ とし, その時間的变化が明らかである場合の理論的な捕食魚の量 $y$ をアナ ログコンピューターで求めたのが Fig. 2 である。

すなわち, 昭和 26 年より 30 年末でのスルメイカの年变化 $x$ を任意函数発生装置でつくつたものが Fig. 2 の折線 (a) であり, これに対応する $y$ が曲線群 (b) として求められている。Fig. 2 では, (2) 式の $D$ は 0.6 で $C$ を $0.05,0.1 ， 0.2 ， 0.4,0.6,1.0$ (曲線群の上より) 飞変光た場合の曲線群である。実際のク口 マグロの年変化と対比してみると $C=0.2$ の場合にほぼ同じ形になる。

生物群集の增大には密度効果を無視することはできない。これを考虑すると，(1)，(2) 式の代りに

$$
\left.\begin{array}{l}
\frac{d x}{d t}=A x-B y \cdot x-\alpha x^{2} \\
\frac{d y}{d t}=-C x+D x \cdot y-\beta y^{2}
\end{array}\right\}
$$

と書くことができる。 $\alpha, \beta$ が密度効果の係数である。この場合についてアナログコンピューターで実際に計 算してみると, 解の形としては密度効果のない場合と殆しど同じょ5なものが得られる。しかしその場合の $C$ や $D$ の倸数の值は密度効果のない場合とは異つていることはもちろんである。このように密度効果を考 光ると否とにかかわらず定性的な形としては同じあのが得られることがわかつたので，以下の取报は $\alpha=$ $\beta=0$ として考光ることにする。

つぎにスルメイカの年変化として昭和 31 年までのをとつた場合を計算してみると， (2) 式の $C$ や $D$ を いか変えてもクロマグロの年変化と似た形を $y$ として得ることができなかつた。すなわち昭和 30 年まで ならばスルメイカとクロマグロは（1）式（2）式であらわされる捕食魚被捕食魚関係として解释することも できようが，昭和 31 年の変動はそれだけでは説明し得ないことが明らかになつた。

\section{4. クロマクロと沿岸魚種との関係}

スルメイカとの関係のみではクロマグロの変動を説明できなくなつたので, 次に沿岸魚種との関係をみて

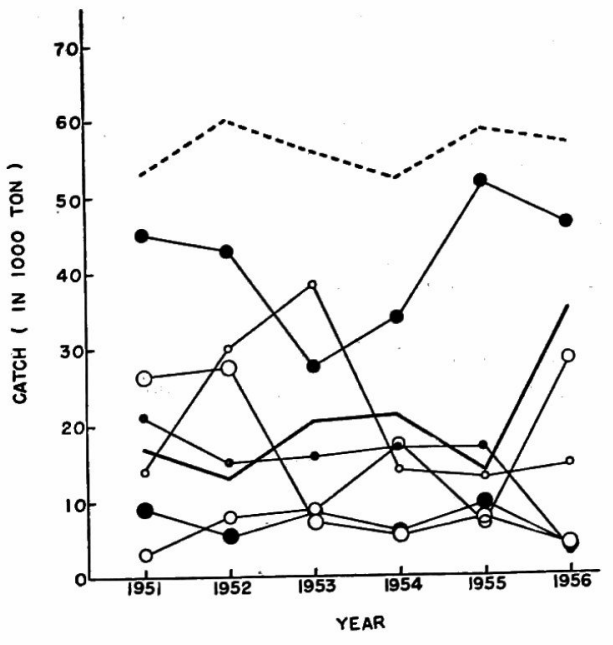

Fig. 3. Yearly variations in catch of bluefin tuna (thick solid line) and coastal fishes for the years 1951 to 1956 .
-: sardine
0 : pampanos
-: anchovy
0 : mackerels
-: round herring $\bigcirc$ : common squid
Dotted line: total of coastal fishes.

みよう。Fig. 3 亿扮もな沿岸魚種の年変化を示し

てある。点線はそれらの総量である。

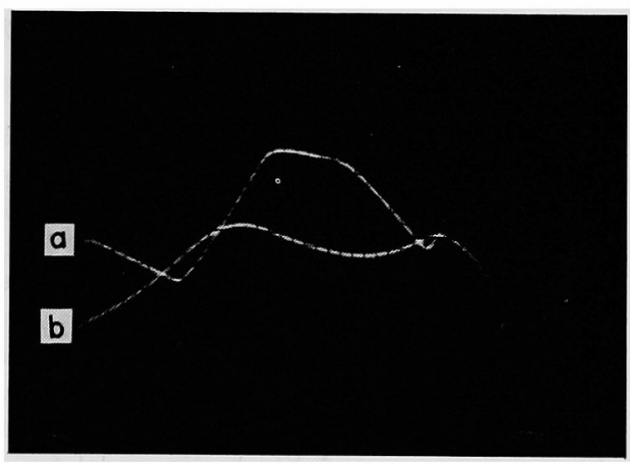

Fig. 4. Theoretical variation of total stock of coastal fishes (curve, b) and actual variation of bluefin tuna (broken line, a) for the years 1951 to 1956 . Explanations for solving the theoretical one are the same as in Fig. 2. As the actual variation of total of coastal fishes is similar to theoretical one, it is not unreasonable to conclude that bluefin tuna and coastal fishes are in predatory relationships. 


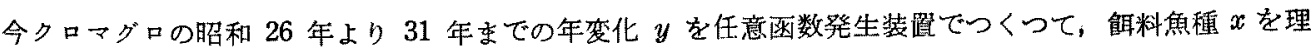
論的に求めるとすると（1）式のみ孝用いればよい。Fig. 4 はその結果であつて，折線（a）は央際のクロマ グロ $(y)$ であり，曲線 (b) は $x$ の理論值で, パラメターの值は (1) 式の $A=0.96, B=1.6$ の場合であ る。この $x$ の形と沿岸魯種の年変化と形の似ているものは焦種別にはなく, 沿岸魚種総量 (Fig. 3 の点 線）が似ている。このことはクロマグロと沿岸焦種総量との間炕捕食魚——被捕食魚関俰があり，それは VOLTERRA の式で説明されることも可能であることを示している。

\section{5. 考察}

南海区水域の魚種間関係が VOLTERRA の式であらかされるか否かをアナロダコンピューターで計算した 結果を示したのが以上述へててきたところであり，クロマグロとスルメイカとは昭和 30 年までは捕食魚— 被捕食魚関倸がなり立つが，昭和 31 年も含めた資料ではこの関倸は見出されず，その場合にはクロマグロ と沿岸魚種総量とにこのような関係が見出された。な特，つぎのよ5な 2,3 の前提があることを注意す心 きである。

以上の取报で筫源の大きさは漁獾量と相対的に比例することを仮定している。㴔獲量は分つているが， 資源量は不明である。普通には資源量の指数として単位源萑量当りの漁獲量を以つてするが，一般にそれと 海猚量とは比例することが多いので，この報告では㴔蒦量の変化で以つて資源量の目安としている。このこ とがみとめられない場合には相刘資源量で計算しなければならない。

焦種間関係のパラメターの推定值は一応記してあるが，この值はあくまでる定性的なるのであつて，たと 觉ば密度效果を考虑するならば推定值は変つてくる。だが形としては大体同じものを得るから VOLTERRA の式があてはまるか否かを判定する定性的な考察にはどちらでる同じである。ゆえにパラメタ一の推定值は 絁対值とはみなさす相対值としてみるべきものである。

これらの前提あるいは仮定のむとで，クロマグッとスルメイカむたは沿岸魚種との関係が捕食魚一被捕 食焦関係として考光てもよいことがわかつた。しかしクロマグロの胃内容物の種類と量，クロマグロの分布 区域の季節的変化，クロマグロ体重分布の経年変化 ${ }^{7)}$ 等を考光に入れて取报つたものでなく，統計資料より のみの結論であるからこのような生物学的基礎については別検討されねばならないだろう。

終りKフナログコンピニーターの計算に多大の労をわずらわした嶺山美和子氏に梁く感謝する。

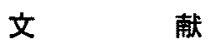

1）横田滝雄：魚類の群聚について，昭和 30 年底魚担当宫会釉資料，(1955).

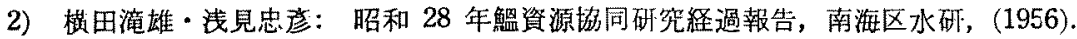

3) 農林水産技術会議：昭和 31 年度水産資源に関する矿㠰協議会経過概要，(1957).

4) BARTLETT, M.S.: On theoretical models for competitive and predatory biological systems, Biometrika, 44, 27 42, (1957).

5) Leslie, P.H.: An Analysis of the data for some experiments carried out by Gause with populations of the protozea, Paramecium aurelia and Paramecium caudatum, Biometrika, 44, 314 327, (1957).

6) - A Stochastic model for studying the properties of certain biological system by numerical methods, Biometrika, 45, 16 31, (1958).

7）山中一：クロマグロの研究－I．潐獾物の体生分布にみられる Mode，南海区水啡報告，9，125〜 135, (1958). 